\title{
Ovarian Cancer pT1 TNM Finding v6
}

National Cancer Institute

\section{Source}

National Cancer Institute. Ovarian Cancer PT1 TNM Finding v6. NCI Thesaurus. Code C60904.

Ovarian cancer with tumor confined to one or both ovaries. (from AJCC 6th Ed.) 